\title{
Scales of Justice: Is there A Geographic Bias in Environmental Equity Analysis?
}

\author{
Brett M. Baden \\ Assistant Professor \\ Department of Urban and Environmental Policy and Planning \\ Tufts University \\ 97 Talbot Avenue \\ Medford, MA 02155 \\ Douglas S. Noonan \\ Assistant Professor \\ School of Public Policy \\ Georgia Institute of Technology \\ Rama Mohana Turaga \\ Ph.D. Candidate \\ School of Public Policy \\ Georgia Institute of Technology
}

[Final version published as: Baden, B. M., Noonan, D. S., \& Turaga, R. M. R. (2007). Scales of justice: Is there a geographic bias in environmental equity analysis? Journal of Environmental Planning and Management, 50(2), 163-185. doi:10.1080/09640560601156433]

\begin{abstract}
Many empirical environmental justice (EJ) studies lack a systematic framework in which to undertake research and interpret results. This paper characterizes the conventional EJ study and examines how results can be influenced by the choice of the spatial scale and scope of analysis. After thoroughly examining a sample of prominent EJ studies, a conventional EJ study is performed for (Superfund) National Priorities List sites. The sensitivity of these results to changes in scale and scope choices demonstrates the observed inconsistency in the empirical literature. Implications for interpreting existing EJ research and conducting future EJ research are discussed.
\end{abstract}




\section{Introduction}

Environmental justice (EJ) is both a growing social movement and a public policy goal. The concept of EJ developed as widespread concerns about toxins in the environment were integrated with the goals of civil rights, Native American, and labor activists, and in turn supported by activism and research from academia (Bryant and Mohai, 1992; Cole and Foster, 2001). This paper addresses methodological challenges of the research that has served as the bulwark for the environmental justice movement.

The paper is organized as follows. Section 2 outlines the primary methodological challenges inherent in environmental justice research, introduces the common features of conventional environmental justice research, and discusses how results may vary based upon methodological assumptions. Section 3 reviews how the empirical EJ literature addresses those methodological challenges. Next, Section 4 presents statistical analyses of hazardous facilities on the Superfund National Priorities List (NPL) to demonstrate the sensitivity of the results of an EJ analysis to differences in methodological assumptions. The results of this analysis are then reviewed in context of existing environmental justice research and policy formulation.

\section{Conventional EJ Research and Methodological Challenges}

Environmental justice is concerned with the equitable distribution of environmental hazards. As such, EJ is inherently empirical insofar as it refers to the observed co-location of waste sites and community demographics. While EJ began to grow as a movement in response to attempts to 
locate facilities in minority areas, the movement did not coalesce around the idea that a pattern of disproportionate impact existed nationwide until the release of "Toxic Waste and Race in the United States” in 1987 (Commission for Racial Justice, 1987). A growing body of research on the characteristics of communities near hazardous facilities followed. Much of that literature focuses on the many methodological issues associated with empirical EJ analyses (e.g., Brown, 1995; Mohai, 1995; Anderton, 1996; Weinberg, 1998; Bowen and Wells, 2002; Maantay, 2002; Ringquist, 2005). This paper addresses the methodological choices of scale (i.e., areal unit of analysis) and scope (i.e., the geographic bounds of the study area). ${ }^{1}$

The challenges of scale and scope can be seen in presidential Executive Order 12898. EO 12898 directs federal agencies to "make achieving environmental justice part of its mission" and identifies minority communities as those where the percentage minority is "meaningfully greater than the minority population percentage in the general population or other appropriate unit of geographic analysis” (Council on Environmental Quality, 1997). There is some guidance on the appropriate unit of geographic analysis, which may be "a governing body’s jurisdiction, a neighborhood, census tract, or other similar unit that is to be chosen so as to not artificially dilute or inflate the affected minority population.” This begs the questions of what constitutes artificial dilution or inflation, and is there a systematic bias across geographic units of analysis? EO 12898 recognizes that methodological choices may affect results yet offers little guidance for policy-relevant analyses.

The researcher's choices of study scale and scope are no small matter. Without much guidance from theory or policy directives, researchers have taken many different approaches. The choices 
of areal unit in the EJ literature spans individual- or firm-level studies to national-level analyses. The existing research also includes a great diversity of scope choices, from the city level to the nation as a whole.

Underlying processes that jointly lead to the location of people and environmental hazards are rarely modeled (most EJ studies consider equilibrium outcomes). Such a structural model is well beyond the scope of this article, although we do discuss the implications in the conclusion. In identifying the sensitivity of EJ evidence to choices of scale and scope, we make no claims based in theory or otherwise - about which choices (if any) are correct, unbiased, appropriate, or relevant for policy. Arguably, environmental inequity at any scale is evidence of injustice and motivates policy to correct the injustice. (Put another way, just because evidence of injustice is apparent at one scale and not at another does not negate the evidence of inequity.)

\subsection{The MAUP}

The choice of unit of analysis poses a very difficult problem for EJ researchers. The modifiable areal unit problem (MAUP) consists of choosing the proper areal unit to analyze aggregate data sources. The "modifiable" component of the problem has to do with the potential to choose different areal units to analyze the same occurrences. MAUP is composed of two separate parts, scale and zoning (Fotheringham and Wong, 1991; Jelinski and Wu, 1996; Wrigley et al., 1996).

The scale component arises when the resolution of analysis varies, typically where smaller areal units can be added up to form larger aggregated areal units. For a given region, shrinking the scale can affect the variance in the observed characteristic. When a broader stochastic data 
generating process dominates the region, shrinking the spatial scale (i.e., higher resolution) of analysis can yield an increased variance because larger scales mask the underlying variation. On the other hand, shrinking the scale and increasing the number of areal units, like increasing the sample size, can lead to reduction in observed variance. This can follow when spatial clustering occurs and disaggregation tends to yield more observations tightly grouped around the mean. Generally, without strong spatial clustering, larger spatial scales are expected to exhibit smaller variances as aggregated means regress to regional averages. The tendency for aggregated units to contain correlated values concerns the second component of MAUP, zoning (or gerrymandering).

The zoning component arises when a given region is divided into different areal sub-units not merely by disaggregating into small sub-units. The effects of the zoning component of MAUP are ambiguous. They depend on the distribution of values and the method of zoning. Alternative zoning schemes typically influence the variance observed in values across areal units. The debates surrounding political redistricting plans offer excellent examples of the sensitivity of the zones' observed values and the variance in those values. Zones drawn around clusters of similar values can amplify underlying variance while zones drawn around clusters of dissimilarity can mask underlying variance.

\subsection{Scope}

The issue of scope concerns the geographic domain that is studied. Environmental justice studies of the U.S. have examined cities, counties, states, sub- and multi-state regions, and the nation as a whole. In some cases, a jurisdictional argument may be made based on the hazard type being studied - that the area studied should be appropriate to the jurisdiction of the level of 
governance responsible for regulating that hazard. However, this rationale becomes complicated when multiple jurisdictions may have regulatory and remediation responsibilities and power. Moreover, underlying natural, social, and market forces may induce hazards or people to spillover jurisdictional boundaries (e.g., downwind or downstream runoff, "white flight,” pollution havens).

What is important is that the choice of scope can influence the results of analysis. Whether the data exhibit correlations between the location of hazards and certain groups can hinge on the presence of sufficient variation in environmental conditions and in demographics in the region. For instance, if downtowns host more poor minorities and also more pollution relative to other areas, then restricting the scope to downtowns may actually understate the larger spatial correlation between poor minorities and pollution. Choosing a particular region or jurisdiction can amount to sampling on the dependent variable if that area or policy is more or less likely to exhibit certain environmental conditions (e.g., presence of a Superfund site). The scope decision rule thus becomes crucial. Been and Gupta (1997), McMaster et al. (1997), Bowen (2001), and Ringquist (2005) discuss scope selection further.

\section{Empirical Analyses of Environmental Justice ${ }^{2}$}

While many studies include explanations for their specific areal unit choices, several authors offer general recommendations for areal unit choice. These recommendations are mixed. Cutter et al. (1996) and Dolinoy and Miranda (2004) argue for using small scales like block groups in their multi-scale analyses. Hockman and Morris (1998) opt for the larger zip-code scale to avoid artificially inflating or diluting the correlation. Krieg (1998b) argues that municipalities should 
be the areal unit of choice to correct for tract size variance. Taquino et al. (2002) suggest constructing community areas (larger than zip code areas) as the unit of analysis. In his comprehensive review of methodologies and research, Bowen (2001) suggests using smaller scales of analysis since fewer assumptions about variable stationarity over distance must be maintained for smaller areal units and cautions against sampling on the dependent variable (i.e., narrowly choosing a sample based on what findings are desired - thus guaranteeing that conclusion). Ringquist (2005), drawing from a meta-analysis of 49 environmental equity studies, makes the stronger claim that the magnitude of inequity coefficients should increase with the level of aggregation. He favors disaggregated units or those matching sites' impact areas.

110 empirical EJ studies are summarized here with respect to scale and scope effects. ${ }^{3}$ Variation in findings by areal unit choice has been found at national, state, and metropolitan level scopes. ${ }^{4}$ Some of the locally focused studies, however, have not identified differences at different scales. ${ }^{5}$ A few studies have proceeded beyond simple two-scale analysis and explored several scale choices at the same scope. ${ }^{6}$ The majority of these studies found consistent signs but differences in magnitudes for EJ variables.

Some studies have examined scale and scope variations together. Asch and Seneca (1978) found different results at the national level than when they focused on cities and concluded that national analysis was too aggregated. McMaster et al. (1997) discussed the variability of results over both scope and scale, within Hennepin County, Minnesota. At the county level (scope), significant racial effects are found using tracts (scale) that are not found at the city level (scope) using block groups (scale). While this study provided an important discussion regarding hazard 
type, exposure measurement, scale, and scope, there was no systematic presentation of how the results varied for the same scope using different scales. The same criticism applies to Bowen et al. (1995) who looked at Toxic Release Inventory (TRI) facilities by county in Ohio and by tract in Cuyahoga County. They argued that results for county (scale) within state-level (scope) analyses are likely to reflect minority concentrations in urban areas only, and that such correlations are likely to be specious. They advocated more micro-level analysis, such as by tract within county (where they found no race effect).

Tables $1 \mathrm{~A}$ and $1 \mathrm{~B}$ illustrate the variation in EJ findings by scale and scope of analysis. The tables display the three most studied demographic variables: \% Black, \% Hispanic, and Income. The Income category refers to studies of household income or, lacking that, an income-related variable like percentage in poverty. For studies that examined percentage minority, the results are listed under both \% Hispanic and \% Black or under \% Black as indicated in the body of that paper. Studies containing no results for a variable category (at a particular scope and scale) receive no entry in that cell.

The numbers included in the cells of Tables 1A and 1B correspond to each study's number in the References section. Studies are listed by the appropriate areal unit of analysis and scope of analysis based on whether the results for the variable of interest are statistically significant or not at the $95 \%$ confidence level. In most cases, when effects are statistically significant, they are as predicted by models of environmental injustice (i.e., positive associations between percentage minority and hazards, and negative associations between income and hazards). When a statistically significant effect has a sign that is contradictory to the environmental justice 
expectations, that study appears in bold italics in that cell. In some cases, EJ analyses have used quadratic income terms to estimate an "inverted U-Shape” path for the effect of higher incomes on pollution; pollution increases with income and then declines at higher levels. Since the primary trend for these studies is an upward linear relationship, such results are entered based on the coefficient of the linear term.

Some studies are included in multiple columns because the study performs the analysis at multiple scales of analysis. For example, in the Tract column for National Scope in Table 1A, the " 2 " in the $\mathrm{Y}$ and $\mathrm{N}$ columns reports that Anderton et al. (1994a) found that \% Black and \% Hispanic were positively associated with transfer, storage, and disposal facilities (TSDF), but only the \% Hispanic effect was significantly different from zero. Results are averaged for studies that performed different regressions for different types of hazards. For example, Hird and Reese (1998) found positive, significant race effects in 12 cases and negative, significant race effects in 5 cases (out of 19 cases). This is reported as a positive, significant race effect.

Tables 1A and 1B are split by hazard types. The physical hazard locations (Table 1A) include studies that address a variety of sites: Superfund; Resource, Conservation and Recovery Act (RCRA) TSDF sites; and other similar environmental hazards listed by state agencies or other data-collecting organizations. Included with these studies are analyses that looked at site expansion decisions (Hamilton, 1993, 1995) and site remediation decisions (Lavelle and Coyle, 1992; Viscusi and Hamilton, 1999; Zimmerman, 1996). Table 1B Environmental Quality includes studies that focus primarily on quantities of generated emissions and ambient environmental quality or risk measures. In most cases, these studies involve airborne pollutants. 
Taken altogether, Tables 1A and 1B suggest some generalizations about the prominent EJ literature. First, there are many different combinations of scale and scope. The literature cited covers most of these combinations, with a notable exception of nationwide studies at the block group level and metropolitan-area studies using counties and zip codes. Not surprisingly, most results appear along the main diagonal of Table 1A. Nationwide studies tend to use larger units of analysis, while studies of smaller regions tend to use smaller units of analysis. Moreover, most studies examine the presence of hazardous sites (see Table 1A), rather than more dataintensive dependent variables like emissions levels or another measure that allows risk levels to vary across sites (see Table 1B).

Second, studies typically find evidence of injustice, but there is substantial variability in the literature. Studies at smaller scales (e.g., tract, block group) appear to exhibit more statistically insignificant findings than at larger scales. This result may be due to aggregation bias (Cutter et al., 1996; Ringquist, 2005) or may follow more intuitive explanations (e.g., Hockman and Morris, 1998) that expect higher correlations at larger units of analysis because small scales diminish variability in demographics and hence their correlations with pollution. A few studies reveal injustice against whites or wealthy groups at different scales and scopes and for different types of disamenities. Individual studies often examine all three of these demographic variables, yet they rarely tackle multiple scopes or more than one or two units of analysis. Even though the literature altogether covers most of the cells in Tables $1 \mathrm{~A}$ and $1 \mathrm{~B}$, this coverage offers little systematic analysis of MAUP and the implications of many research design choices made by analysts. 
This review of empirical studies of EJ shows that scale and scope may be influential factors that contribute to the differences among widely varying studies. However, this conclusion is limited by the variety among the research considered. Closer inspection of Table $1 \mathrm{~A}$ suggests that the distribution of statistically significant findings is not independent of scale. ${ }^{7}$ Conversely Table 1B suggests that the distribution of statistically significant findings is not independent of scope. Many possible explanations exist for any systematic variation in the literature, including heterogeneity of the underlying data or varying empirical methods. While the literature may exhibit some sensitivity to scale and scope choice, this does not necessarily imply that results within a particular study are sensitive to scale and scope choices. The next section addresses within-study variation in an application that examines EJ and Comprehensive Environmental Response, Compensation and Liability Information System (CERCLIS) NPL sites.

\section{Scale and Scope Induced Variation: An Application Using CERCLIS NPL}

This study contributes a systematic demonstration of variability of results by areal unit and by national and sub-national geographic scopes - something missing in the literature to date. As demonstrated earlier, the EJ literature spans a wide range of scale/scope choice combinations and several studies have employed multiple scales and scopes. Although Anderton et al. (1994a, 1994b) were national in scope, their analysis did not systematically address all the possible census designated areal units. Cutter et al. (1996) and Taquino et al. (2002) addressed different areal units, but did not address a national scope. McMaster et al. (1997) presented results for different scopes, yet was limited in the region it covered. Sui (1999) presented a very comprehensive analysis by various scales but was also limited by his choice of scope. A national 
analysis is very important because regional studies are liable to the criticism of sampling on the dependent variable in the choice of study area. ${ }^{8}$ The following analysis estimates measures of environmental equity at each variable and each combination of scale and scope in Table 1A.

Just as the EJ literature spans this broad spectrum of fine- and coarse-grained analysis over small and large regions, and results clearly vary across studies, our analysis does likewise to explore the sensitivity of results within-study.

This sensitivity analysis demonstrates the effects of the choices of scale and scope within a study of NPL “Superfund” sites. Much of the environmental justice literature pays special attention to the Superfund sites (e.g., Baden and Coursey, 2002; Heitgard and Lee, 2003; Hird, 1993; Stretsky and Hogan, 1998; Troester, 1997). These high-profile sites represent the some of the most high-risk, controversial disamenities in the country. The presence of NPL sites commonly serves as an indicator of environmental contamination and risk.

Table 2: Mean Values of Demographic Variables with and without NPL Sites, by Unit of Analysis

\begin{tabular}{|l|c|c|c|c|c|c|c|c|}
\hline & \multicolumn{9}{|c|}{ Unit of analysis: } \\
\hline & \multicolumn{2}{|c|}{ County } & \multicolumn{2}{c|}{ Zip Code } & \multicolumn{2}{c|}{ Tract } & \multicolumn{2}{c|}{ Block Group } \\
\hline \multicolumn{1}{|c|}{ with NPL site? } & $\mathrm{Y}$ & $\mathrm{N}$ & $\mathrm{Y}$ & $\mathrm{N}$ & $\mathrm{Y}$ & $\mathrm{N}$ & $\mathrm{Y}$ & $\mathrm{N}$ \\
\hline \% black & 8.9 & 8.7 & 9.1 & $7.1^{*}$ & 10.0 & $13.7^{*}$ & 10.0 & $13.2^{*}$ \\
\hline \% Hispanic & 7.9 & 8.5 & 9.3 & $6.4^{*}$ & 9.4 & $12.7^{*}$ & 9.0 & $12.3^{*}$ \\
\hline Income (\$1000s) & 39.7 & $33.4^{*}$ & 45.5 & $39.8^{*}$ & 44.6 & 43.8 & 44.7 & 44.3 \\
\hline * significant at 1\% \%
\end{tabular}

A cursory inspection of the distribution of NPL sites around the country may not find conclusive evidence of inequity. Simple two-tailed t-tests demonstrate this by testing whether areas with or without NPL sites have the same demographic characteristics. Table 2 shows the mean values of percent black, percent Hispanic, and income by area (i.e., county, zip code, tract, block group) 
for those with and without sites. This bivariate relationship between NPL sites and justicerelated demographic variables suggests little systematic evidence of injustice against minorities or the poor.

The average percent black is higher in areas with NPL sites, for analyses at the county and zipcode levels. Yet, at the smaller scales, the percent black is lower in tracts and block groups with NPL sites (10\%) than those without (13-14\%). The percent Hispanic in areas with NPL sites is only greater at the zip-code level, otherwise it is actually lower. Household income is higher in areas with NPL sites than in those without, significantly so at larger scales. Overall, for the national scope, bivariate tests find the expected evidence of injustice only for black and Hispanic at zip-code scale. Otherwise, no evidence of injustice is found. Yet, even though 24 of the 110 EJ studies reviewed hinge on these sorts of bivariate correlations, the bivariate approach is arguably flawed because of omitted variable bias or other spurious correlations.

A multivariate regression analysis replicates more conventional approaches of the literature (see e.g., Anderton et al., 1994; Been, 1995; Cutter et al., 1996). The basic logit model tests whether hazardous sites are located in disproportionately minority or poor areas. The variables chosen reflect those commonly used in the environmental justice literature that uses regression analysis. While other variables and other, possibly superior, statistical models are available, the logit model offers a straightforward estimation procedure consistent with the previous literature. ${ }^{9}$

The dependent variable is a binary variable for whether or not an areal unit has an NPL site. 1,633 sites comprise the NPL dataset used here (EPA, 2002). Predictors in the model include percent black, percent Hispanic, and median income for that areal unit. The model incorporates 
as control variables percent of population that is urban, whether the areal unit is in an MSA, and population density. It also includes state-level fixed effects. All demographic variables are from the 2000 Census. Table 3 presents the results for the national sample.

Estimating the same model at different scales (county, zip code, tract, and block group) and scopes (nation, state $\{$ California $\}$, city $\{$ Los Angeles County $\}$ ) demonstrates the sensitivity of results. Table 4 presents the results of the same analysis using the state of California as the scope of choice. All of the included variables are identical to the national-level models. Table 5 presents the same model for the zip code, tract, and block group level for the Los Angeles county metropolitan area. These regressions omit both the MSA and the urbanicity variables since the study population is urban in an MSA.

Spatial patterns in the data call into question the fixed-effects logit model. More sophisticated models take into account spatial heterogeneity - a particularly acute concern for the national scope - and other forms of spatial dependence in the data could be developed (Anselin, 2001; Anselin and Cho, 2002). In this context, there may be little reason to restrict logit coefficients to be invariant across space, to expect an observation's error term to be uncorrelated with its neighbor's, or to assume that an observation's probability of hosting a site is independent of its neighbor's. Among the many alternatives to deal with this problem, two pragmatic approaches are presented here. First, state-level fixed effects are included to capture spatially defined unobserved factors. This accounts for unobserved heterogeneity among spatial clusters (at the state level). Second, estimating the logit model separately at multiple scopes allows for spatial heterogeneity, where model coefficients can vary by region. The models in Table 3 use the same 
coefficients for all observations in the nation, but separate models for states or cities can account for spatial heterogeneity in model specification. Examples for California and Los Angeles are given in Tables 4 and 5, respectively. Additionally, the results in Tables 4 and 5 were checked against a linear probability model with spatial errors, with a spatial weights matrix based on contiguity. The basic results remain unchanged. ${ }^{10}$ Overall, this analysis takes some basic steps to mitigate some of the spatial dependence in the data, and more sophisticated spatial regression models are eschewed at this point to preserve consistency across models and comparability with the conventional EJ literature. Only 4 of the 110 papers reviewed included explicit modeling of spatial dependence.

Table 3 displays evidence of environmental inequities by race and income. In a nationwide analysis of NPL locations, this logit specification identifies significantly higher probabilities of hosting a site in an areal unit as the percent black increases, across all four geographic scales of analysis. The result is almost the same for percent Hispanic. The county scale of analysis, however, indicates weaker evidence of inequities with respect to percent black, as the coefficient is not significant at the $5 \%$ level. Moreover, the evidence of inequities for Hispanics not only disappears, it reverses at the county scale of analysis. Given the other controls in the model, at the $10 \%$ level, counties with greater proportions of Hispanics are less likely to host NPL sites. Similarly, poorer areas appear more likely to host NPL sites only at the smaller scales. The significance of the inequities with respect to income disappears as the scale increases, and the sign even reverses at the county scale (although much uncertainty surrounds that estimate). 
While changing the scale of analysis can reverse the sign and significance of justice variables, the results for the control variables remain consistent across scales. The sign and significance of the control variables do not vary across scales. As expected, NPL sites are more frequent in MSAs that serve as population centers with more urban populations. The negative effect of density suggests that, controlling for the area's population, larger areas are more likely to contain NPL sites. More manufacturing employment is associated with better odds of hosting a site.

Table 3: Logit Regression Results for NPL Sites Nationwide

\begin{tabular}{|c|c|c|c|c|}
\hline & $\begin{array}{l}\text { County } \\
\text { Coef. }\end{array}$ & $\begin{array}{l}\text { Zip Code } \\
\text { Coef. }\end{array}$ & $\begin{array}{l}\text { Tract } \\
\text { Coef. }\end{array}$ & $\begin{array}{c}\text { Block Group } \\
\text { Coef. }\end{array}$ \\
\hline Black & $\begin{array}{r}0.9554^{*} \\
(1.67)\end{array}$ & $\begin{array}{c}0.7307^{\star * *} \\
(3.15)\end{array}$ & $\begin{array}{l}0.7417^{\star \star \star} \\
(4.27)\end{array}$ & $\begin{array}{l}0.8349^{\star \star \star} \\
(5.44)\end{array}$ \\
\hline Hispanic & $\begin{array}{r}-1.2679^{*} \\
(1.75)\end{array}$ & $\begin{array}{l}0.834^{\star \star \star} \\
(2.86)\end{array}$ & $\begin{array}{c}1.2804^{\star \star *} \\
(5.66)\end{array}$ & $\begin{array}{l}1.2103^{\star \star \star} \\
(5.91)\end{array}$ \\
\hline Income & $\begin{array}{r}0.0098 \\
(1.25)\end{array}$ & $\begin{array}{r}-0.0015 \\
(0.72)\end{array}$ & $\begin{array}{c}-0.0099 * \star \star \\
(5.55)\end{array}$ & $\begin{array}{l}-0.0102^{\star \star \star} \\
(6.61)\end{array}$ \\
\hline Density & $\begin{array}{c}-491.2545^{\star \star \star} \\
(3.41)\end{array}$ & $\begin{array}{c}-580.4366^{\star \star \star} \\
(11.16)\end{array}$ & $\begin{array}{c}-1045.179 * \star \star \\
(20.37)\end{array}$ & $\begin{array}{c}-1318.672^{\star \star \star} \\
(23.77)\end{array}$ \\
\hline Population & $\begin{array}{c}0.0008^{\star \star \star} \\
(2.82)\end{array}$ & $\begin{array}{c}0.0318^{\star \star *} \\
(12.35)\end{array}$ & $\begin{array}{l}0.1044^{\star \star \star} \\
(9.04)\end{array}$ & $\begin{array}{l}0.2268^{\star \star \star} \\
(11.85)\end{array}$ \\
\hline Urbanicity & $\begin{array}{c}2.6761^{\star \star \star} \\
(11.1)\end{array}$ & $\begin{array}{c}1.2516^{\star \star \star} \\
(10.82)\end{array}$ & $\begin{array}{c}0.3749^{\star \star \star} \\
(4.25)\end{array}$ & $\begin{array}{l}0.4447^{\star \star \star} \\
(5.69)\end{array}$ \\
\hline MSA & $\begin{array}{c}0.3883^{\star \star *} \\
(2.97)\end{array}$ & $\begin{array}{c}0.3614^{\star \star *} \\
(3.75)\end{array}$ & $\begin{array}{c}0.2885^{\star \star *} \\
(3.76)\end{array}$ & $\begin{array}{l}0.4372^{\star \star \star} \\
(6.06)\end{array}$ \\
\hline$N$ & 3178 & 31627 & 65744 & 209648 \\
\hline $\operatorname{LR} x^{2}(7)$ & 375.9 & 694.01 & 1032.91 & 1559.05 \\
\hline Prob $>x^{2}$ & 0 & 0 & 0 & 0 \\
\hline State fixed-effects & 48 & 51 & 51 & 51 \\
\hline
\end{tabular}

Three states dropped in county-level analysis due to no variation in dependent variable.

Absolute value of $z$ statistics in parentheses

* significant at $10 \%$; ** significant at $5 \%$; *** significant at $1 \%$

\section{Variable descriptions:}

MSA - Dummy variable taking a value of 1 if areal unit is in or abuts a metropolitan statistical area

Density - Population density of areal unit, measured as total population divided by area (in $\mathrm{m}^{2}$ )

Population - Total population (in 1000s) of areal unit

Urbanicity - Share of total population that is classified as "urban population" in areal unit

Black - Share of population identifying self as black or African American or Negro in areal unit

Hispanic - Share of population identifying self as Hispanic or Latino in areal unit, not mutually exclusive with black and white

Income - Median household income (in \$1000s) in areal unit 
Table 4: Logit Regression Results for NPL Sites in California

\begin{tabular}{|c|c|c|c|c|}
\hline & $\begin{array}{l}\text { County } \\
\text { Coef. }\end{array}$ & $\begin{array}{l}\text { Zip Code } \\
\text { Coef. }\end{array}$ & $\begin{array}{l}\text { Tract } \\
\text { Coef. }\end{array}$ & $\begin{array}{c}\text { Block Group } \\
\text { Coef. }\end{array}$ \\
\hline Black & $\begin{array}{r}8.4923 \\
(0.90)\end{array}$ & $\begin{array}{r}1.7960 \\
(1.61)\end{array}$ & $\begin{array}{c}2.6643^{\star \star \star} \\
(3.30)\end{array}$ & $\begin{array}{c}2.5056^{\star \star \star} \\
(3.58)\end{array}$ \\
\hline Hispanic & $\begin{array}{r}-1.5997 \\
(0.76)\end{array}$ & $\begin{array}{r}0.5222 \\
(0.89)\end{array}$ & $\begin{array}{c}1.7631^{\star \star \star} \\
(3.56)\end{array}$ & $\begin{array}{c}1.4085^{\star \star \star} \\
(3.34)\end{array}$ \\
\hline Income & $\begin{array}{r}-0.0317 \\
(0.89)\end{array}$ & $\begin{array}{r}-0.0080 \\
(1.10)\end{array}$ & $\begin{array}{r}-0.0016 \\
(0.31)\end{array}$ & $\begin{array}{r}-0.0026 \\
(0.67)\end{array}$ \\
\hline Density & $\begin{array}{r}-520.4362^{\star \star} \\
(2.10)\end{array}$ & $\begin{array}{c}-323.0422^{\star \star \star} \\
(3.36)\end{array}$ & $\begin{array}{c}-806.2588^{\star \star *} \\
(5.34)\end{array}$ & $\begin{array}{c}-1137.5920^{\star \star \star} \\
(5.15)\end{array}$ \\
\hline Population & $\begin{array}{r}-0.0002 \\
(0.64)\end{array}$ & $\begin{array}{r}0.0129^{*} \\
(1.86)\end{array}$ & $\begin{array}{r}0.0662^{*} \\
(1.71)\end{array}$ & $\begin{array}{l}0.1292^{\star * *} \\
(3.47)\end{array}$ \\
\hline Urbanicity & $\begin{array}{r}6.4045 \\
(1.36)\end{array}$ & $\begin{array}{l}1.3198^{\star \star \star} \\
(2.58)\end{array}$ & $\begin{array}{r}0.3111 \\
(0.75)\end{array}$ & $\begin{array}{r}0.6601^{*} \\
(1.79)\end{array}$ \\
\hline MSA & $\begin{array}{r}-0.9066 \\
(0.64)\end{array}$ & $\begin{array}{r}0.2578 \\
(0.45)\end{array}$ & $\begin{array}{r}-0.5528 \\
(1.23)\end{array}$ & $\begin{array}{r}-0.1632 \\
(0.38)\end{array}$ \\
\hline constant & $\begin{array}{r}-2.2721 \\
(1.07)\end{array}$ & $\begin{array}{c}-4.1011^{\star \star \star} \\
(7.83)\end{array}$ & $\begin{array}{c}-3.7195^{\star \star \star} \\
(7.44)\end{array}$ & $\begin{array}{c}-4.8089 * \star \star \\
(11.03)\end{array}$ \\
\hline$N$ & 58 & 1674 & 7036 & 22007 \\
\hline Wald $x^{2}(7)$ & 6.89 & 34.45 & 73.05 & 89.67 \\
\hline Prob $>x^{2}$ & 0.4405 & 0 & 0 & 0 \\
\hline Pseudo $\mathrm{R}^{2}$ & 0.1784 & 0.0563 & 0.1190 & 0.1425 \\
\hline
\end{tabular}

Absolute value of $\mathrm{z}$ statistics in parentheses, based on robust standard errors

* significant at $10 \%$; ** significant at $5 \%$; $* * *$ significant at $1 \%$

When the state of California is considered alone, there is also evidence of disproportionate exposure. The percentage black is significant at the tract and block-group scales and grows in significance and magnitude as the areal unit shrinks. Tracts and block groups with higher percentages of Hispanics also appear to be more likely to host sites, though this evidence is absent at larger scale resolutions. (The sign switches to negative for Hispanic at the county level, although it and the model as a whole lack significance.) Income is an insignificant predictor of 
site hosting at all scales. Except for Density, the significance of control variables' effects varies across scales, although their signs are stable for significant coefficients.

Table 5: Logit Regression Results for NPL Sites in L.A. County

\begin{tabular}{|c|c|c|c|}
\hline & $\begin{array}{l}\text { Zip Code } \\
\text { Coef. }\end{array}$ & $\begin{array}{l}\text { Tract } \\
\text { Coef. }\end{array}$ & $\begin{array}{c}\text { Block Group } \\
\text { Coef. }\end{array}$ \\
\hline Black & $\begin{array}{r}-1.6793 \\
(0.44)\end{array}$ & $\begin{array}{r}-1.6315 \\
(0.38)\end{array}$ & $\begin{array}{r}-0.1132 \\
(0.05)\end{array}$ \\
\hline Hispanic & $\begin{array}{r}1.8837 \\
(1.30)\end{array}$ & $\begin{array}{r}1.9898^{*} \\
(1.76)\end{array}$ & $\begin{array}{c}2.3699^{\star \star \star *} \\
(3.55)\end{array}$ \\
\hline Income & $\begin{array}{r}-0.0063 \\
(0.42)\end{array}$ & $\begin{array}{c}-0.0452^{\star *} \\
(2.49)\end{array}$ & $\begin{array}{c}-0.0186^{\star *} \\
(2.12)\end{array}$ \\
\hline Density & $\begin{array}{c}-242.3725^{\star *} \\
(1.90)\end{array}$ & $\begin{array}{c}-602.3844^{\star \star \star} \\
(3.97)\end{array}$ & $\begin{array}{c}-629.9667^{\star \star \star} \\
(3.76)\end{array}$ \\
\hline Population & $\begin{array}{r}0.0014 \\
(0.12)\end{array}$ & $\begin{array}{c}0.3305^{\star \star \star} \\
(2.72)\end{array}$ & $\begin{array}{r}0.1242 \\
(0.94)\end{array}$ \\
\hline constant & $\begin{array}{c}-2.7715^{\star \star} \\
(2.39)\end{array}$ & $\begin{array}{c}-3.3728^{\star \star \star} \\
(2.96)\end{array}$ & $\begin{array}{c}-4.464^{\star \star \star} \\
(4.84)\end{array}$ \\
\hline$N$ & 278 & 2047 & 6278 \\
\hline Wald $x^{2}(5)$ & 8.83 & 35.58 & 79.93 \\
\hline Prob $>x^{2}$ & 0.1161 & 0 & 0 \\
\hline Pseudo $\mathrm{R}^{2}$ & 0.0467 & 0.1600 & 0.1353 \\
\hline
\end{tabular}

Absolute value of $\mathrm{z}$ statistics in parentheses, based on robust standard errors

* significant at $10 \%$; ** significant at $5 \%$; *** significant at $1 \%$

For Los Angeles County, the nature of inequities changes considerably. The logit model reveals areas with greater proportions of African Americans to be no more or less likely to host NPL sites than other areas. Tracts and block groups with higher percentages of Hispanics, however, are more likely to host NPL sites. Likewise, income appears inversely related to the probability of having a site at the tract and block-group resolutions. The model predicts very poorly at the larger, zip-code scale - finding no significantly different odds of hosting a site by race or income. The other independent variables display patterns consistent with Tables 3 and 4 (no sign changes). 
Table 6 demonstrates how findings using the same data and statistical model vary by scale and scope. A “ 0 ” indicates that the coefficient was not statistically different than zero. A “+” indicates a positive relationship and a “-” indicates a negative relationship.

Table 6 Summary of Scale and Scope Effects on EJ Variables

\begin{tabular}{|c|c|c|c|c|c|}
\hline & & County & Zip Code & Tract & Block Group \\
\hline \multirow{3}{*}{ Nation } & \% Black & $+^{*}$ & $+^{* * *}$ & $+^{* * *}$ & $++^{* * *}$ \\
\hline & \% Hispanic & $-^{*}$ & $+^{* * *}$ & $+^{* * *}$ & $+^{* * *}$ \\
\hline & Income & 0 & 0 & $-^{*}$ & $--^{* * *}$ \\
\hline \multirow{3}{*}{ California } & \% Black & 0 & 0 & $+^{* * * *}$ & $+^{* * *}$ \\
\hline & \% Hispanic & 0 & 0 & $+^{* * *}$ & $++^{* * *}$ \\
\hline & Income & 0 & 0 & 0 & 0 \\
\hline \multirow{3}{*}{$\begin{array}{l}\text { L.A. } \\
\text { County }\end{array}$} & \% Black & $\mathrm{n} / \mathrm{a}$ & 0 & 0 & 0 \\
\hline & \% Hispanic & $\mathrm{n} / \mathrm{a}$ & 0 & $+^{*}$ & $++^{* * *}$ \\
\hline & Income & $\mathrm{n} / \mathrm{a}$ & 0 & $-^{* *}$ & $-^{* *}$ \\
\hline
\end{tabular}

When looking across scopes within a particular scale, Table 6 highlights the potential for very sensitive results. Significant national effects at the county and zip-code scales disappear at subnational scopes. While significant inequities for Hispanics appear at each scope at both tract and block-group scales, the inequities are more scope-sensitive for blacks and the poor. Inequities for blacks fade at the local level, and inequities for the poor fades at the state level. This inconsistency likely reflects MAUP and the underlying spatial heterogeneity in processes that give rise to the observed distribution of people and sites. The results of Table 6 must also be taken in context. When reviewing Table 6 it is important to remember the limitations of drawing inferences about the extent of inequities without explicitly linking the sample data to the underlying processes being modeled. 
At the national scope there is some evidence of environmental injustice in 2000, similar to the 1990 findings of Hird (1993), Zimmerman (1996), and Hamilton and Viscusi (1999). However, these results are inconsistent with the findings from 2000 of Heitgard and Lee (2003). In terms of California and Los Angeles County, there have been no comparable published studies to date that have specifically looked at CERCLIS sites. The results from L.A. County at the tract level are most consistent with the results of Szasz and Meuser (1997) or Lejano and Iseki (2001) though the hazard studied differs.

The findings for percentage black at the national and state scopes and for percentage Hispanic at the city scope agree with the predictions of greater significance at smaller scales of areal unit choice of Sui (1999) and Dolinoy and Miranda (2004). They are not consistent with the expectations of Cutter et al. (1996), Hockman and Morris (1998), and Ringquist (2005). That the income effect fades at larger scales resembles Ringquist’s (2005) result for poverty and Sui’s (1999) result for income. Other results, especially the inconsistency of effect for Hispanics at the national scope, are difficult to reconcile with predictions in the literature except perhaps the methodological caution of Fotheringham and Wong (1991) that changes in scale and zoning will have unpredictable effects on multivariate regression.

\section{Discussion}

Arguments for using one areal unit instead of another abound in the empirical literature. The approach of these studies is summarized and examined in Williams (1999), who suggests that the unit of analysis should correspond to the community in question. EJ researchers have tended to favor the areal unit approximating spatial exposure patterns and scope approximating the 
regulatory jurisdiction for the hazard studied. Theoretical guidance is limited. Guidance from policy directives like EO 12898 remains ambiguous. At the core of this problem is the MAUP.

As a general solution to MAUP, Wrigley et al. (1996) offer some hope for generalizable solutions - which rely on modeling the processes by which individuals or smaller units aggregate into larger units and then adjusting the results observed at one scale of aggregation to estimate effects at another. Fotheringham and Wong (1991) recommend that results for different areal units should be presented to assess the stability of results across scales. In terms of environmental justice, Sui (1999) and Bowen and Wells (2002) also argue that a systematic evaluation of the effects of alternate areal unit choices is necessary for any empirical investigation to be meaningful. While cumbersome and time consuming, this approach appears to be the most rigorous. Accordingly, the original EJ analysis presented here examines multiple scales and scopes in a consistent statistical framework.

The idea of potential bias is very important in empirical studies. Executive Order 12898 warns against bias, but provides no real guidance to researchers other than not to "artificially inflate or artificially deflate" the demographic pattern of interest. The underlying distribution of data will determine the findings, and the MAUP still lacks a general solution. The effects of varying scale and scope depend on the underlying distribution of data. Moreover, "artificial" inflation or dilution implies a "natural" (or unbiased) aggregate measure of a population that may not exist. The notion of "biased" estimates depends on a clear notion of the "true" measure of inequity, a concept not readily identifiable in the EJ literature. If biases cannot be predicted based on 
methodological changes and if there is no clear criterion for the best choice of areal unit, the idea of bias itself may not be useful for the study of environmental justice.

Substantively, the analysis of Superfund NPL sites finds robust evidence of disproportionate exposure of Blacks at the national scope. Strong evidence of disproportionate exposure of Hispanics also exists at smaller scales at the national scope, although significantly the sign reverses at the county scale (i.e., more Hispanic counties are less likely to contain NPL sites). Disproportionate exposure for low-income people appears to be restricted to smaller areal units of analysis. Both Blacks and Hispanics also face disproportionate exposure at the tract and block-group levels in California; Hispanics and low-income residents face disproportionate exposure in Los Angeles County.

The review of the literature and systematic analysis of NPL site hosting provides several insights. First, choice of scale and scope matters in theory and in practice. Findings can vary with scale and scope choice, both within-study and across-studies. This variation does not negate the existence of disproportionate exposure at any one scale. However, EJ researchers can improve the credibility of their analysis and robustness of their results by reporting sensitivity analyses similar to those undertaken in this paper.

The longstanding problems of MAUP and ecological fallacy notwithstanding, there are intuitive reasons why we might expect results to vary as they do in Tables $3-5$. Intuitions about land use markets and transportation costs suggest some reasons for systematic variation in results. As land markets reflect local environmental quality, the poor (and the correlated minority 
populations) get priced out of areas with less disamenities. More local scales should thus tend to exhibit stronger evidence of disproportionate impact, while large scales (e.g., county) dilutes this effect. There may even be opposite effects at larger scales if firms purposively locate near urbanized and economically developed (and hence wealthier) areas. In addition, locally unwanted land uses (LULUs) are also likely to be sited in politically disenfranchised communities (often poor or minority). Holding all else equal, smaller areas (e.g., block groups) may have less population -- hence less political voice than larger areas. This political intuition reinforces the market intuition about expected scale effects, consistent with the results in Tables $3-5$.

For the choice of the geographic scope of study, we might expect smaller scopes to exhibit weaker evidence of injustice if these samples suffer from selection on the dependent variable. Otherwise, scope effects should remain ambiguous and depend on how and what sample was selected.

The possibility that evidence of injustice is sensitive to researchers' scale and scope choices presents several intriguing implications. It points to important criteria for the courts and lawmakers' to consider in identifying and remedying injustice. EJ-related policy would also be improved by more clarification concerning the criteria for the identification of injustice. EJ policy design should be mindful of the persistence of the MAUP and inherent data limitations. More guidance about what constitutes injustice could well be coupled with explicit recognition a la the Precautionary Principle - that restrictive evidentiary standards ought not deter efforts to improve environmental equity. 
This sensitivity also makes clear the risks of researchers accidentally overlooking the injustice that exists because they looked at the wrong area or units. Alternatively, and more cynically, it suggests that researchers may be able to make methodological choices to conceal (or reveal) evidence of injustice. Have or will researchers select their methods to affect their findings? Such a question is beyond the scope of this analysis. All this analysis shows is how certain methodological choices can matter a great deal in this context. Hopefully, these findings will spur additional inquiries into the processes that give rise to observed inequities (at given scale/scope pairs). That shift in focus should lend guidance to researchers making methodological choices as well as lead to improved public policy.

Improving the theoretical models that motivate the empirical EJ inquiries offers an excellent opportunity to advance the literature. The current emphasis on the equity of distribution of environmental disamenities focuses attention on equilibrium outcomes of several very complex systems. Explicit consideration of these systems can suggest scales and scopes appropriate to test the hypotheses to which they give rise. More attention could be paid to identifying the dynamic forces that give rise to inequity rather than on continued observations of static inequity. Many studies show hazards are more likely to be found where minorities or low-income people are. Yet whether this is the result of particular political or market institutions (as opposed to some identified counterfactual), prejudice, or something else often remains neglected. Policy and management reforms depend on better understanding the processes that give rise to the observed inequities regardless of scale and scope. 
Table 1A Physical Hazard Locations

\begin{tabular}{|c|c|c|c|c|c|c|c|c|c|c|c|}
\hline 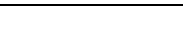 & Scale & $\mathrm{Co}$ & nty & Zip & Code & & & & & Bloc & group \\
\hline & & Sign & cant? & Sign & icant? & Sigr & sant? & Signi & cant? & Signi & cant? \\
\hline & & $\mathrm{Y}$ & $\mathrm{N}$ & $Y$ & $\mathrm{~N}$ & $Y$ & $\mathrm{~N}$ & $\mathrm{Y}$ & $\mathrm{N}$ & $\mathrm{Y}$ & $\mathrm{N}$ \\
\hline & National & & & & & & & & & & \\
\hline & $\%$ Black & $\begin{array}{l}36,45,52 \\
53,110\end{array}$ & $31,47,102$ & $\begin{array}{l}26,43,47 \\
64,87\end{array}$ & 46,48 & $\begin{array}{l}3,4,33 \\
103\end{array}$ & 44 & $\begin{array}{l}5,12,13,32 \\
51\end{array}$ & $2,3,4,44,80$ & 8,49 & 33 \\
\hline & \% Hispanic & $45,52,53$ & 31,102 & $26,43,87$ & & $\begin{array}{l}3,4,33,44 \\
103\end{array}$ & & $\begin{array}{l}12,13,32, \\
44\end{array}$ & $\begin{array}{l}2,3,4,5,51 \\
80\end{array}$ & 8 & 33 \\
\hline & Income & $\begin{array}{l}31,36,45 \\
52,53\end{array}$ & 102,110 & $26,43,48,87$ & 46,47 & $\begin{array}{l}3,4,33,44 \\
103\end{array}$ & & $\begin{array}{l}2,3,4,5,12 \\
13,44\end{array}$ & 32,80 & 8,33 & 49 \\
\hline & State or $\mathrm{R}$ & gion & & & & & & & & & \\
\hline & $\%$ Black & $\begin{array}{l}11,27,28 \\
68,74,85, \\
100,101\end{array}$ & $30,98,102$ & $\begin{array}{l}35,37,55, \\
61,87\end{array}$ & 45,98 & $82,85,93$ & & 85,93 & $\begin{array}{l}3,28,32,98, \\
108\end{array}$ & $\begin{array}{l}79,84,106 \\
107\end{array}$ & 28,98 \\
\hline & \% Hispanic & $68,100,101$ & 102 & $55,61,87$ & 45 & 82,93 & & 93 & $3,32,108$ & 79 & \\
\hline $\begin{array}{l}\text { CERCLIS, } \\
\text { CERLCIS }\end{array}$ & Income & $\begin{array}{l}11,27,28, \\
30,74,98, \\
100,101\end{array}$ & 68,102 & $\begin{array}{l}35,37,45 \\
61,87,98\end{array}$ & 55 & 82,93 & & 93,108 & $3,28,32,98$ & $\begin{array}{l}28,79,84, \\
106,107\end{array}$ & 98 \\
\hline NPL, & City or Me & & & & & & & & & & \\
\hline $\begin{array}{l}\text { RCRA } \\
\text { TSDF } \\
\text { or other }\end{array}$ & $\%$ Black & & & $\begin{array}{l}58,60,89, \\
95,105\end{array}$ & 35,65 & $14,81,95$ & $9,66,88,91$ & $\begin{array}{l}11,19,20 \\
32,42,56 \\
57,70,81 \\
82,95,96\end{array}$ & $\begin{array}{l}9,29,14,63 \\
88,91,94\end{array}$ & $\begin{array}{l}29,54,56,57 \\
70,71,95\end{array}$ & 50,91 \\
\hline & \% Hispanic & & & $\begin{array}{l}58,60,65, \\
95\end{array}$ & 89 & $9,81,88,95$ & 14,91 & $\begin{array}{l}9,20,32,57, \\
81,82,95\end{array}$ & $\begin{array}{l}14,88,91, \\
94\end{array}$ & $57,71,95$ & 50,91 \\
\hline & Income & & & $\begin{array}{l}35,58,60 \\
65,89,95\end{array}$ & & $9, \mathbf{8 8 , 9 1 , 9 5}$ & $14,66,81$ & $\begin{array}{l}11,20,42, \\
57,81,82, \\
\mathbf{8 8}, 91,94, \\
95,96 \\
\end{array}$ & $\begin{array}{l}9,14,29,32, \\
63\end{array}$ & $\begin{array}{l}29,54,57,70 \\
71,91,95\end{array}$ & \\
\hline
\end{tabular}


Table 1B Environmental Quality

\begin{tabular}{|c|c|c|c|c|c|c|c|c|c|c|c|}
\hline \multirow{15}{*}{$\begin{array}{l}\text { Emissions } \\
\text { and } \\
\text { ambient } \\
\text { levels }\end{array}$} & \multirow{3}{*}{ Scale } & \multirow{2}{*}{\multicolumn{2}{|c|}{$\begin{array}{c}\text { County } \\
\text { Significant? }\end{array}$}} & \multirow{2}{*}{\multicolumn{2}{|c|}{$\begin{array}{c}\text { Zip Code } \\
\text { Significant? }\end{array}$}} & \multirow{2}{*}{\multicolumn{2}{|c|}{$\begin{array}{c}\text { Tract+ } \\
\text { Significant? }\end{array}$}} & \multirow{2}{*}{\multicolumn{2}{|c|}{$\begin{array}{c}\text { Tract } \\
\text { Significant? }\end{array}$}} & \multirow{2}{*}{\multicolumn{2}{|c|}{$\begin{array}{c}\text { Blockgroup } \\
\text { Significant? }\end{array}$}} \\
\hline & & & & & & & & & & & \\
\hline & & $Y$ & $\mathrm{~N}$ & $\mathrm{Y}$ & $\mathrm{N}$ & $\mathrm{Y}$ & $\mathrm{N}$ & $\mathrm{Y}$ & $\mathrm{N}$ & $\mathrm{Y}$ & $\mathrm{N}$ \\
\hline & \multicolumn{11}{|l|}{ National } \\
\hline & $\%$ Black & $\begin{array}{l}\text { 1,31,4153, } \\
92\end{array}$ & 7 & $6,18,86,87$ & & 90 & & & & & \\
\hline & \% Hispanic & 31,53 & & 86,87 & & 90 & & & & & \\
\hline & Income & $\begin{array}{l}7,31, \mathbf{4 1 , 5 3}, \\
92\end{array}$ & 1 & $6,18,86$ & 87 & 90 & & & & & \\
\hline & \multicolumn{11}{|c|}{ State or Region } \\
\hline & $\%$ Black & $\begin{array}{l}15,21,67,99, \\
109\end{array}$ & 16 & 87 & 6 & $\begin{array}{l}17,69,72,83 \\
88\end{array}$ & 78 & 75 & 72 & 62,86 & 22,79 \\
\hline & \% Hispanic & 15 & 16,99 & 87 & & $\begin{array}{l}17,69,72,83 \\
88\end{array}$ & 78 & 72,75 & & 62,86 & 22,79 \\
\hline & Income & 21,25 & $15,16,67,99$ & 87 & 6 & $\begin{array}{l}17,69,78,83, \\
88\end{array}$ & & 75 & 72 & 22,86 & 62,79 \\
\hline & \multicolumn{11}{|c|}{ City or Metro } \\
\hline & $\%$ Black & 38 & & 34 & 59 & & $15,39,97$ & $\begin{array}{l}23,24,73,76, \\
77,88,104\end{array}$ & $\begin{array}{l}7,10,34,39, \\
42,82,99\end{array}$ & $24,34,40$ & \\
\hline & \% Hispanic & & & & 59 & 39 & 15,97 & $39,76,77,88$ & $10,82,99$ & & \\
\hline & Income & 38 & & 34,59 & & 39,97 & 15 & $\begin{array}{l}7,10,23,24 \\
73,77,82,88 \\
104\end{array}$ & $\begin{array}{l}34,39,42,76 \\
99\end{array}$ & 24 & 34,40 \\
\hline
\end{tabular}




\section{References}

Adeola, Francis O. (2000) Endangered Community, Enduring People: Toxic Contamination, Health, and Adaptive Responses in a Local Context, Environment and Behavior, vol. 32, no. 2, pp. 20-249.

Allen, David W. (2001) Social Class, Race, and Toxic Releases in American Counties, 1995, Social Science Journal, vol. 38, pp. 13-25. \{1\}

Anderson, Andy B., Douglas L. Anderton, and John M. Oakes (1994) Evaluating TSDF Siting Over the Past Two Decades, Waste Age, pp. 83-97. $\{2\}$

Anderton, Douglas L. (1996) Methodological Issues in the Spatiotemporal Analysis of Environmental Equity, Social Science Quarterly, vol. 77, no. 3, pp.508-515.

Anderton, Douglas L., A. B. Anderson, P. H. Rossi, J. M. Oakes, and M. R. Fraser (1994a) Environmental Equity: The Demographics of Dumping, Demography, vol. 31, no. 2, pp. 229-248. $\{3\}$

Anderton, Douglas L., A. B. Anderson, P. H. Rossi, J. M. Oakes, E. W. Weber, and E. J. Calabrese (1994b) Hazardous Waste Facilities: Environmental Equity in Metropolitan Areas, Evaluation Review, vol. 18, no. 2, pp. 123-140. \{4\}

Anderton, Douglas L., John Michael Oakes, and Karla L. Egan (1997) Environmental Equity in Superfund: Demographics of the Discovery and Prioritization of Abandoned Toxic Sites, Evaluation Review, vol. 21, no. 2, pp. 3-26. \{5\}

Anselin, Luc (2001) Spatial Econometrics, in Baltagi, Badi H., ed. Companion to Theoretical Econometrics (Oxford: Basil Blackwell), pp. 310-330.

Anselin, Luc and Wendy K. Tam Cho (2002) Spatial Effects and Ecological Inference, Political Analysis, vol. 10, no. 3, pp. 276-297.

Arora, Seema and Timothy N. Cason (1998) Do Community Characteristics Influence Environmental Outcomes? Evidence from the Toxics Release Inventory, Journal of Applied Economics, vol. 1, no. 2, pp. 413-453. \{6\}

Asch, Peter and Joseph J. Seneca (1978) Some Evidence on the Distribution of Air Quality, Land Economics, vol. 54, no. 3, pp. 278-297. $\{7\}$

Atlas, Mark (2002) Few and Far Between? An Environmental Equity Analysis of the Geographic Distribution of Hazardous Waste Generation, Social Science Quarterly, vol. 83, no. 1, pp.365-378. $\{8\}$ 
Baden, Brett and Don Coursey (2002) The Locality of Waste in the City of Chicago: A Demographic, Social, and Economic Analysis, Resource and Energy Economics, vol. 24, pp. 53-93. $\{9\}$

Baden, Brett, Douglas Noonan, and Julian Agyeman (2005) A Meta Analysis of Methodological Issues in Environmental Justice Research, unpublished manuscript.

Bailey, Adrian J., James D. Sargent, and Megan K. Blake (1998) A Tale of Two Counties: Childhood Lead Poisoning, Industrialization, and Abatement in New England, Economic Geography, pp. 96-111. \{10\}

Been, Vicki (1994) Locally Undesirable Land Uses in Minority Neighborhoods: Disproportionate Siting or Market Dynamics? Yale Law Journal, vol. 103, no. 6, pp. 1383-1422. $\{11\}$

Been, Vicki (1995) Analyzing Evidence of Environmental Justice, Journal of Land Use and Environmental Law, vol. 11, no. 1, pp. 1-36. \{12\}

Been, Vicki and Francis Gupta (1997) Coming to the Nuisance or Going to the Barrios? A Longitudinal Analysis of Environmental Justice Claims, Ecology Law Quarterly, vol. 24, no. 1, pp. 1-56. $\{13\}$

Boer, J. T., J. Manuel Pastor, J. L. Sadd, and L. D. Snyder (1997) Is there environmental racism? The demographics of hazardous waste sites in Los Angeles County, Social Science Quarterly, vol. 78, no. 4, pp. 793-810. \{14\}

Bowen, William M. (2001) Environmental Justice Through Research-Based Decision Making (New York, NY: Garland Publishing).

Bowen, W. M., M. J. Salling, K. E. Haynes, and E. J. Cyran (1995) Toward Environmental Justice, Spatial Equity in Ohio and Cleveland, Annals of the Association of American Geographers, vol. 84, no. 4, pp. 641-663. \{15\}

Bowen, William M. and Michael V. Wells (2002) The Politics and Reality of Environmental Justice: A History and Considerations for Public Administrators and Policy Makers, Public Administration Review, vol. 62, no. 6, pp. 688-698.

Brajer, Victor and Jane V. Hall (1992) Recent Evidence on the Distribution of Air Pollution Effects, Contemporary Policy Issues, vol. X, pp. 63-71. \{16\}

Brajer, Victor and Jane V. Hall (2005) Changes in the Distribution of Air Pollution Exposure in the Los Angeles Basin from 1990 to 1999, Contemporary Economic Policy, vol. 23, no. 1, pp. 50-58. $\{17\}$

Brown, Phil (1995) Race, Class, and Environmental Health: A Review and Systemization of the Literature, Environmental Research, vol. 69, pp. 15-30. 
Brooks, Nancy and Rajiv Sethi (1997) The Distribution of Pollution: Community Characteristics and Exposure to Air Toxics, Journal of Environmental Economics and Management, vol. 32, pp. 233-250. $\{18\}$

Bryant, Bunyan and Paul Mohai, eds. (1992) Race and the Incidence of Environmental Hazards: A Time for Discourse (Boulder, CO: Westview Press).

Bullard, Robert D. (1983) Solid Waste Sites and the Black Houston Community, Sociological Inquiry, vol. 53, no.2/3, pp. 273-288. $\{19\}$

Burke, Loretta (1993) Race and Environmental Equity: A Geographic Analysis in Los Angeles, Geo Info Systems, vol. 3, no. 9, pp. 44-47, 50. \{20\}

Cameron, Trudy Ann and Ian T. McConnaha (2006) Evidence of Environmental Migration, Land Economics, vol. 82 no. 2, pp. 273-290.

Cassidy, Elizabeth A., Rebecca P. Judge, and Paul M. Sommers (2000) The Distribution of Environmental Justice: A Comment, Social Science Quarterly, vol. 81, no. 3, pp. 877878. $\{21\}$

Centner, Terrence J., Warren Kriesel, and Andrew G. Keeler (1996) Environmental Justice and Toxic Releases: Establishing Evidence of Discriminatory Effect Based on Race and Not Income, Wisconsin Environmental Law Journal, vol. 3, pp. 119-158. \{22\}

Chakraborty, Jayajit and Marc P. Armstrong (1996) Using Geographic Plume Analysis to Assess Community Vulnerability to Hazardous Accidents, Computers, Environment, and Urban Systems, vol. 19, no. 5/6, pp. 341-356. \{23\}

Chakraborty, Jayajit and Marc P. Armstrong (1997) Exploring the Use of Buffer Analysis for the Identification of Impacted Areas in Environmental Equity Assessment, Cartography and Geographic Information Systems, vol. 24, no. 3, pp. 145-157. \{24\}

Cole, Luke W. and Sheila R. Foster (2001) From the Ground Up: Environmental Racism and the Rise of the Environmental Justice Movement (New York: New York University Press).

Cohen, Maurie (1997) The Spatial Distribution of Toxic Chemical Emissions: Implications for Nonmetropolitan Areas, Society and Natural Resources, vol. 10, pp. 17-41. \{25\}

Commission for Racial Justice (1987) Toxic Waste and Race in the United States: A National Report on the Racial and Socio-economic Characteristics of Communities with Hazardous Waste Sites (New York: United Church of Christ). \{26\}

Council on Environmental Quality (1997) Environmental Justice: Guidance Under the National Environmental Policy Act (Washington, DC: Executive Office of the President). 
Crawford, Colin (1996) Analyzing Evidence of Environmental Justice: A Suggestion for Professor Been, Journal of Land Use and Environmental Law, vol. 12, no. 1, pp. 103117. $\{27\}$

Cutter, S. L., D. Holm, and L. Clark (1996) The Role of Geographic Scale in Monitoring Environmental Justice, Risk Analysis, vol. 16, no. 4, pp. 517-526. \{28\}

Cutter, Susan L., Michael E. Hodgson, and Kirstin Dow (2001) Subsidized Inequities: The Spatial Patterning of Environmental Risks and Federally Assisted Housing, Urban Geography, vol. 22, no. 1, pp. 29-53.\{29\}

Cutter, Susan L. and William D. Solecki (1996) Setting Environmental Justice in Space and Place: Acute and Chronic Airborne Toxic Releases in the Southeastern United States, Urban Geography, vol. 17, no. 5, pp. 380-399. \{30\}

Daniels, Gynis and Samantha Friedman (1999) Spatial Inequality and the Distribution of Industrial Toxic Releases: Evidence from the 1990 TRI, Social Science Quarterly, vol. 80, no. 2, pp. 244-262.\{31\}

Davidson, P. and D. L. Anderton, (2000) Demographics of Dumping II: A National Environmental Equity Survey and the Distribution of Hazardous Material Handlers, Demography, vol. 37, no. 4, pp. 461-466. \{32\}

Derezinski, Daniel D., Michael G. Lacy, and Paul B. Stretesky (2003) Chemical Accidents in the United States, 1990-1996, Social Science Quarterly, vol. 86, no. 1, pp. 122-143.\{33\}

Dolinoy, Dana C. and Lynn Miranda (2004) GIS Modeling of Air Toxics Releases from TRIReporting and Non-TRI-Reporting Facilities: Impacts for Environmental Justice, Environmental Health Perspectives, vol. 112, no. 17, pp. 1717-1724.\{34\}

Downey, Liam, (1998) Environmental Justice: Is Race or Income a Better Predictor? Social Science Quarterly, Vol. 79, No., 4, pp. 766-778. \{35\}

Elliott, M.R., Y. Wang, R.A. Lowe, and P.R. Kleindorfer (2004) Environmental Justice: Frequency and Severity of US Chemical Industry Accidents and the Socioeconomic Status of Surrounding Communities, Journal of Epidemiology and Community Health, vol. 58, issue 1, pp. 1-15.\{36\}

Faber, Daniel M. and Eric J. Krieg (2002) Unequal Exposure to Ecological Hazards: Environmental Injustices in the Commonwealth of Massachusetts, Environmental Health Perspectives, vol. 110, supplement 2, pp. 277-288.\{37\}

Fotheringham, A. S. and D. W. S. Wong (1991) The Modifiable Areal Unit Problem in Multivariate Statistical Analysis, Environment and Planning A, vol, 23, pp. 1025-1044. 
Freeman, A. Myrick III (1973) Income Distribution and Environmental Quality, in Enthoven, Alain C. and A. Myrick Freeman III, eds., Pollution, Resources, and the Environment, (New York, New York: WW Norton and Company), pp. 100-106. \{38\}

Fricker, Ronald D., Jr. and Nicolas W. Hengartner (2001) Environmental Equity and the Distribution of Toxic Release Inventory and Other Environmentally Undesirable Sites in Metropolitan New York City Environmental and Ecological Statistics, vol. 8, pp. 33-52. $\{39\}$

Gayer, Ted (2000) Neighborhood Demographics and the Distribution of Hazardous Waste Risks: An Instrumental Variables Estimation, Journal of Regulatory Economics, vol. 17, no. 2, pp. 131-155. $\{40\}$

Gianessi, Leonard P., Henry M. Peskin, and Edward Wolff (1979) The Distributional Effects of Uniform Air Pollution Policy in the United States, Quarterly Journal of Economics, vol. 93, no. 2, pp. 281-301. $\{41\}$

Glickman, Theodore S. (1999) Measuring Environmental Equity with Geographical Information Systems, in Wallace E. Oates, ed., The RFF Reader in Environmental and Resource Management (Washington DC: Resources for the Future). $\{42\}$

Goldman, Benjamin A. and Laura Fitton (1994) Toxic Waste and Race Revisited: An Update of the 1987 Report on the Racial and Socioeconomic Characteristics of Communities with Hazardous Waste (Washington, DC: Center for Policy Alternatives, 1994). $\{12\}\{43\}$

Graham, John D., Nancy Dean Beaulieu, Dana Sussman, March Sadowitz, and Yi-Ching Li (1999) Who Lives Near Coke Plants and Oil Refineries? An Exploration of the Environmental Inequity Hypothesis? Risk Analysis, vol. 29, no. 2, pp. 171-186. \{44\}

Greenberg, Michael (1993) Proving Environmental Inequity in Siting Locally Unwanted Land Use Risk: Issues in Health and Safety, vol. 4, no. 1, pp. 235-252.\{45\}

Greenstone, Michael and Justin Gallagher (2005) Does Hazardous Waste Matter? Evidence from the Housing Market and the Superfund Program, FEEM Working Paper No. 149.05 Available at SSRN: http://ssrn.com/abstract=840207 .

Gupta, Shreekant, George van Houten, and Maureen Cropper (1996) Paying for Permanence: An Economic Analysis of EPA's Cleanup Decisions at Superfund Sites, RAND Journal of Economics, vol. 27, no. 3, pp. 563-582.\{46\}

Hamilton, James T. (1993) Politics and Social Costs: Estimating the Impact of Collective Action on Hazardous Waste Facilities, Rand Journal of Economics, vol. 24, no. 1, pp. 101-125. $\{47\}$

Hamilton, James T. (1995). Testing for Environmental Racism: Prejudice, Politics, Political Power? Journal of Policy Analysis and Management, vol. 14, no. 1, 107-132. \{48\} 
Hamilton, James T. and W. Kip Viscusi (1999) Environmental Equity at Superfund Sites, in Hamilton, James T. and W. Kip Viscusi Calculating Risks? The Spatial and Political Dimensions of Hazardous Waste Policy (Cambridge, Massachusetts: MIT Press), pp. 157-188. $\{49\}$

Haynes, Kingsley E., Somik V. Lall, and Mark P. Trice (2001) Spatial Issues in Environmental Equity, International Journal of Environmental Technology and Management, vol. 1, no. 1/2, pp. 17-31. $\{50\}$

Heitgard, Janet L. and C. Virginia Lee (2003) A New Look at Neighborhoods near National Priorities List Sites, Social Science and Medicine, vol. 57, pp. 1117-1126. \{51\}

Hird, John A. (1993) Environmental Policy and Equity: The Case of Superfund, Journal of Policy Analysis and Management, vol. 12, no. 2, pp. 323-343. \{52\}

Hird, John A. and Michael Reese (1998) The Distribution of Environmental Quality: An Empirical Analysis, Social Science Quarterly, vol. 79, no. 4, pp. 693-716.\{53\}

Hite, Diane (2000) A Random Utility Model of Environmental Equity, Growth and Change, vol. 31, pp. 40-58. $\{54\}$

Hockman Elaine M. and Charles M. Morris (1998) Progress towards Environmental Justice: A Five-year Perspective of Toxicity, Race, and Poverty in Michigan, 1990-1995 Journal of Environmental Planning and Management, vol. 41, no. 2, pp. 157-176.\{55\}

Hurley, Andrew (1997) Fiasco at Fort Wagner: Environmental Justice and Urban Geography in St. Louis, Environmental History, vol. 2, pp. 460-481.\{56\}

Jacobsen, Jerry O., Nicolas W. Hengartner, and Thomas A. Louis (2005) Inequity Measures for Evaluations of Environmental Justice: A Case Study of Close Proximity to Highways in New York City, Environment and Planning A, vol. 37, pp. 21-43.\{57\}

Jelinski, Dennis E. and Jianguo Wu (1996) The Modifiable Areal Unit Problem and Implications for Landscape Ecology, Landscape Ecology, vol. 11, no. 3, pp. 129-140.

Jerrett, Michael, Richard T. Burnett, Pavlos Kanaroglou, John Eyles, Norm Finkelstein, Chris Giovis, and Jeffrey R. Brook (2001) A GIS - Environmental Justice Analysis of Particulate Air Pollution in Hamilton, Canada, Environment and Planning A, vol. 33, pp. 955-973.

Krieg, Eric J. (1995) A Socio-Historical Interpretation of Toxic Waste Sites: The Case of Greater Boston, The American Journal of Economics and Sociology, vol. 54, no. 1, pp. 1-14.\{58\}

Krieg, Eric J. (1998a) Methodological Considerations in the Study of Toxic Waste Hazards Social Science Journal, vol. 35, no. 2, pp.191-201.\{59\} 
Krieg, Eric J. (1998b) The Two Faces of Toxic Waste: Trends in the Spread of Environmental Hazards, Sociological Forum, vol. 13, no. 1, pp.3-20. \{60\}

Krieg, Eric J. and Daniel R. Faber (2004) Not So Black and White: Environmental Justice and Cumulative Impact Assessments, Environmental Impact Assessment Review, vol. 24, pp. 667-694. $\{61\}$

Kriesel, W., T. J. Centner, and A. J. Keeler (1996) Neighborhood Exposure to Toxic Releases: Are There Racial Inequalities? Growth and Change, vol. 27, pp. 479-499. \{62\}

Lambert, Thomas and Christopher Boerner (1997) Environmental Inequity: Economic Causes, Economic Solution, Yale Journal on Regulation, vol. 14, pp. 195-523. \{63\}

Lavelle, Marianne, and Marcia Coyle (1992) Unequal Protection: The Racial Divide in Environmental Law, National Law Journal, vol. 15, no. 3, pp. S1-S12. \{64\}

Lejano, Raul P. and Hiroyuki Iseki (2001) Environmental Justice: Spatial Distribution of Hazardous Waste Treatment, Storage, and Disposal Facilities in Los Angeles Journal of Urban Planning and Development, vol. 127, no. 2, pp. 51-62.\{65\}

Liu, Feng (1997) Dynamics and Causation of Environmental Equity, Locally Unwanted Land Uses, and Neighborhood Changes, Environmental Management, vol. 21, no. 5, pp. 643656. $\{66\}$

Lopez, Russ (2002) Segregation and Black/White Differences in Exposure to Air Toxics in 1990, Environmental Health Perspectives, vol. 110, supplement 2, pp. 289-295.\{67\}

Maantay, Juliana (2002) Mapping Environmental Injustices: Pitfalls and Potential of Geographic Information Systems in Assessing Environmental Health and Equity, Environmental Health Perspectives, vol. 110, no. 2, pp. 161-171.

Maher, Timothy (1998) Environmental Oppression: Who Is Targeted for Toxic Exposure? Journal of Black Studies, vol. 28, no. 3, pp. 357-367.\{68\}

Margai, Florence Lasana (2001) Health Risks and Environmental Inequity: A Geographical Analysis of Accidental Releases of Hazardous Materials, The Professional Geographer, vol. 53, no. 3, pp. 422-434.\{69\}

McMaster, Robert B., Helga Leitner, and Eric Sheppard (1997) GIS-Based Environmental Equity and Risk Assessment: Methodological Problems and Prospects, Cartography and Geographic Information Systems, vol. 24, no. 3, pp. 172-189. \{70\}

Mennis, Jeremy, (2002) Using Geographic Information Systems to Create and Analyze Statistical Surfaces of Population and Risk for Environmental Justice Analysis, Social Science Quarterly, Vol. 83, No. 1, pp. 281-297. \{71\} 
Mennis, Jeremy L. and Lisa Jordan (2005) The Distribution of Environmental Equity: Exploring the Spatial Nonstationarity in Multivariate Models of Air Toxic Releases, Annals of the Association of American Geographers, vol. 95, no. 2, pp. 249-268. \{72\}

Mielke, H.W., C.R. Gonzales, M.K. Smith, and P.W. Mielke (1999) The Urban Environment and Children's Health: Soil as an Integrator of Lead, Zinc, and Cadmium in New Orleans, Louisiana, USA, Environmental Research Section A, vol. 81, pp.117-129.\{73\}

Mitchell, Jerry T., Deborah S.K. Thomas, Susan L. Cutter (1999) Dumping in Dixie Revisited: The Evolution of Environmental Injustices in South Carolina Social Science Quarterly, Vol. 80, No. 2, pp. 229-243. $\{74\}$

Mohai, Paul (1995) The Demographics of Dumping Revisited: Examining the Impact of Alternate Methodologies in Environmental Justice Research, Virginia Environmental Law Journal, vol. 14, pp. 615-653.

Mohai, Paul and Bunyan Bryant (1998) Is There a "Race" Effect on Concern for Environmental Quality? The Public Opinion Quarterly, vol. 62, no. 4, pp. 475-505.

Morello-Frosch, Rachel, Manuel Pastor, and James Sadd (2001) Environmental Justice and Southern California's Riskscape : The Distribution of Air Toxics Exposures and Health Risks Among Diverse Communities, Urban Affairs Review, vol. 36, no. 4, pp. 551578. $\{75\}$

Morello-Frosch, Rachel, Manuel Pastor Jr., and James Sadd (2002a) Integrating Environmental Justice and the Precautionary Principle in Research and Policy Making: The Case of Ambient Air Toxics Exposure and Health Risks Among Schoolchildren in Los Angeles Annals of the American Academy of Political and Social Science, vol. 584, pp. 47$68 .\{76\}$

Morello-Frosch, Rachel, Manuel Pastor Jr., Carlos Porras, and James Sadd (2002b) Environmental Justice and Regional Inequality in Southern California: Implications for Future Research, Environmental Health Perspectives, vol. 110, supplement 2, pp. 149154. $\{77\}$

Napton, Mary Luanne and Frederick A. Day (1992) Polluted Neighborhoods in Texas: Who Lives There? Environment and Behavior, vol. 24, no. 4, pp. 508-526.\{78\}

Neumann, Catherine M., Debra L. Forman, and Joan E. Rothlein (1998) Hazard Screening of Chemical Releases and Environmental Equity Analysis of Populations Proximate to Toxic Release and Inventory Facilities in Oregon, Environmental Health Perspectives, vol. 106, no. 4. $\{79\}$ 
Noonan, Douglas S., Douglas J. Krupka, and Brett M. Baden (2005) Neighborhood Dynamics and Price Effects of Superfund Site Clean-up, Fiscal Research Center of Georgia State University, Brief/Report \#113.

Oakes, John Michael, Douglas L. Anderton, and Andy B. Anderson (1996) A Longitudinal Analysis of Environmental Equity in Communities with Hazardous Waste Facilities, Social Science Research, vol. 25, pp. 125-148. \{80\}

Pastor, Manuel Jr., Jim Sadd, and John Hipp (2001) Which Came First? Toxic Facilities, Minority Move-In, and Environmental Justice? Journal of Urban Affairs, vol. 23, no. 1, pp. $1-21 .\{81\}$

Pastor, Manuel Jr., James L. Sadd, and Rachel Morello-Frosch (2002) Who’s Minding the Kids? Pollution, Public Schools, and Environmental Justice in Los Angeles, Social Science Quarterly, vol. 83, no. 1, pp. 263-280.\{82\}

Pastor, Manuel Jr., James L. Sadd, and Rachel Morello-Frosch (2004) Waiting to Inhale: The Demographics of Toxic Air Release Facilities in $21^{\text {st }}$-Century California, Social Science Quarterly, vol. 85, no. 2, pp. 420-440. \{83\}

Perlin, Susan A., David Wong, and Ken Sexton (2001) Residential Proximity to Industrial Sources of Air Pollution: Interrelationships Among Race, Poverty, and Age, Journal of the Air and Waste Management Association, vol. 51, pp. 406-421. \{84\}

Pine, John C., Brian D. Marx, and Aruna Lakshmanan (2002) An Examination of Accidental Release Scenarios from Chemical-Processing Sites: The Relation of Race to Distance, Social Science Quarterly, vol. 83, no. 1, pp. 317-331.\{85\}

Pollock, P. H. and M. E. Vittas (1995) Who Bears the Burdens of Environmental Pollution? Race, Ethnicity, and Environmental Equity in Florida. Social Science Quarterly, vol. 76, no. 2, pp. 295-310.\{86\}

Ringquist, Evan J. (1997) Equity and the Distribution of Environmental Risk: The Case of TRI Facilities, Social Science Quarterly, vol. 78, no. 4, pp. 811-829.\{87\}

Ringquist, Evan J. (2005) Assessing Evidence of Environmental Inequities: A Meta-Analysis, Journal of Policy Analysis and Management, vol. 24, no. 2, pp. 223-247.

Robinson, William S. (1950) Ecological Correlations and the Behavior of Individuals. American Sociological Review, vol. 15, pp. 351-57.

Sadd, J. L., J. Manuel Pastor, J. T. Boer, and L. D. Snyder (1999) 'Every Breath You Take...': The Demographics of Toxic Air Releases in Southern California . Economic Development Quarterly, vol. 13, no. 2, pp.107-123. \{88\} 
Shaikh, Sabina L. and John B. Loomis (1999) An Investigation Into the Presence and Consequences of Environmental Inequity in Denver, Colorado, The Social Science Journal, vol. 36, no. 1, pp. 77-92.\{89\}

Shapiro, Marc D. (2005) Equity and Information: Information Regulation, Environmental Justice, and Risks from Toxic Chemicals Journal of Policy Analysis and Management, vol. 24, no. 2, pp. 373-398. $\{90\}$

Sheppard, Eric, Helga Leitner, Robert B. McMaster, and Hongguo Tian (1999) GIS-Based Measures of Environmental Equity: Exploring their Sensitivity and Significance Journal of Exposure Analysis and Environmental Epidemiology, vol. 9, pp. 18-28.\{91\}

Stretesky, Paul B. (2003) The Distribution of Air Lead Levels Across US Counties: Implications for the Production of Racial Inequality Sociological Spectrum, vol. 23, pp. 91-118.\{92\}

Stretesky, P. and M. J. Hogan (1998) Environmental Justice: An Analysis of Superfund Sites in Florida. Social Problems, vol. 45, no. 2, pp. 268-287. \{93\}

Stretesky, Paul, and Michael J. Lynch (1999) Environmental Justice and the Predictions of Distance to Accidental Chemical Releases in Hillsborough County, Florida, Social Science Quarterly, vol. 80, no. 4, pp. 830-846.\{94\}

Sui, Daniel (1999) GIS, Environmental Equity, and the Modifiable Areal Unit Problem (MAUP), in Massimo Craglia and Harlan Onsrud (ed.), Geographic Information Research : Transatlantic Perspectives (London: Taylor and Francis), pp. 41-54. \{95\}

Szasz, Andrew and Michael Meuser (2000) Uninteded, Inexorable: The Production of Environmental Inequalities in Santa Clara County, California, American Behavioral Scientist, vol. 43, no. 4, pp. 602-632.\{96\}

Talih, Makram and Ronald D. Fricker, Jr. (2002) Effects of Neighborhood Demographic Shifts on Findings of Environmental Injustice: A New York City Case Study, Journal of the Royal Statistical Society: Series A, vol. 165, issue 2, pp. 375 \{97\}

Taquino, M., D. Parisi, and D. A. Gill (2002) Units of Analysis and the Environmental Justice Hypothesis: The Case of Industrial Hog Farms. Social Science Quarterly, vol. 83, no. 1, pp. 298-316. \{98\}

Tiefenbacher, John P. and Ronald R. Hagelman, III (1999) Environmental Equity in Urban Texas: Race, Income, and Patterns of Acute and Chronic Toxic Air Releases in Metropolitan Counties, Urban Geography, vol. 20, no. 6, pp. 516-533.\{99\}

Troester, Gianni (1997) Comment: Environmental Justice in EPA Region VII: A Closer Look, The Urban Lawyer, vol. 29, no. 3, pp. 579-594. \{100\} 
U.S. EPA. (2002) CERCLIS database of NPL sites. Updated versions available online at: http://cfpub1.epa.gov/supercpad/cursites/srchsites.cfm

U.S. General Accounting Office (1983) Siting of Hazardous Waste Landfills and Their Correlation with Racial and Economic Status of Surrounding Communities (Washington, DC: US GPO, 1983). \{101\}

U.S. General Accounting Office, (1995) Hazardous and Nonhazardous Waste: Demographics of People Living Near Waste Facilities (Washington, DC: US GPO, 1995). \{102\}

Viscusi, W. Kip and James T. Hamilton (1999) Are Risk Regulators Rational? Evidence from Hazardous Waste Cleanup Decisions, American Economic Review, vol. 89, no. 4, pp. 1010-1027. $\{103\}$

Waller, Lance A., Thomas A. Louis, and Bradley P. Carlin (1997) Bayes Methods for Combining Disease and Exposure Data in Assessing Environmental Justice, Environmental and Ecological Statistics, vol. 4, pp. 267-281.\{104\}

Weinberg, Adam S. (1998) The Environmental Justice Debate: A Commentary on Methodological Issues and Practical Concerns, Sociological Forum, vol. 13, no. 1, pp. 25-32.

White, Harvey L. (1992) Hazardous Waste Incineration and Minority Communities, in Bryant, Bunyan and Paul Mohai, eds., Race and the Incidence of Environmental Hazards: A Time for Discourse, (Boulder, CO: Westview Press), pp. 126-139.\{105\}

Williams, Robert W. (1999) The Contested Terrain of Environmental Justice Research: Community as Unit of Analysis, Social Science Journal, vol. 36, no. 2, pp. 313-328.

Wilson, Sacoby M., Frank Howell, Steve Wing, and Mark Sobsey (2002) Environmental Injustice and the Mississippi Hog Industry Environmental Health Perspectives, vol. 110, supplement 2, pp. 195-201.\{106\}

Wing, Steve, Dana Cole, and Gary Grant (2000) Environmental Injustice in North Carolina's Hog Industry, Environmental Health Perspectives, vol. 108, no. 3, pp. 225-231.\{107\}

Wrigley, Neil, Tim Holt, David Steel, and Mark Tranmer (1996) Analysing, Modeling, and Resolving the Ecological Fallacy. In Longley, Paul and Michael Batty, eds. Spatial Analysis: Modelling in a GIS Environment, (New York: John Wiley \& Sons), pp. 25-40.

Yandle, Tracy and Dudley Burton (1996) Reexamining Environmental Justice: A Statistical Analysis of Hazardous Waste Landfill Siting Patterns in Metropolitan Texas, Social Science Quarterly, vol. 77, no. 3, pp. 477-492. \{108\} 


\title{
Zanobetti, Antonella and Joel Schwartz (2000) Race, Gender, and Social Status as Modifiers of the Effects of PM-10 on Mortality, Journal of Occupational and Environmental Medicine, vol. 42, no. 5, pp. 469-474.\{109\}
}

\author{
Zimmerman, Rae (1993) Social Equity and Environmental Risk, Risk Analysis, vol. 13, no. 6, \\ pp. 649-666. $\{110\}$
}

\begin{abstract}
${ }^{1}$ Alternative terms are used in the literature. For instance, "scale" and "resolution" are often used instead of "scope" and "scale," respectively.

2 This research only considers published studies. To provide comparability concerning areal units the analyses are limited to studies of EJ in the US only. Papers based on survey evidence (such as Adeola, 2000) are not included in Tables $1 \mathrm{~A}$ and $1 \mathrm{~B}$.

${ }^{3}$ The results reported in Tables 1A and 1B (including a thorough review of the literature) are discussed at further length in Baden et al. (2005). This review spans multiple hazard types, methodologies, and study designs, as well as differences in scale and scope.

${ }^{4}$ Anderton et al. (1994a, 1994b) find different results for host tracts and tracts within 2.5 miles of hazardous waste sites at the national level. Derezenski et al. (2003) identify a similar variation in results in their national analysis of host block groups and block groups within 2 miles of a chemical accident. Graham et al. (1999) find that results did not vary in a national analysis of host tract vs. host and adjacent tracts around coke plants and refineries. Baden and Coursey (2002) find that results varied for host tracts vs. host and contiguous tracts around multiple waste site types in Chicago. Fricker and Hengartner (2001) discover a similar pattern at the same scales in New York City. Boer et al. (1997) find similar results for Los Angeles using host tracts and tracts within a 1-mile radius. Mennis and Jordan (2005) also show changes in racial significance for host tracts and tracts within a 5-km buffer for TRI facilities in
\end{abstract} New Jersey. Comparable results are found by Sadd et al. (1999) in southern California for host tracts and tracts within 1 mile of a TRI facility.

${ }^{5}$ Stretesky and Hogan (1998) do not find a difference in class and racial significance for NPL sites at the host tract vs. host tract and contiguous tract scales for Florida. Jacobsen et al. (2005) do not observe difference at the tract vs. block group level for proximity to highways in New York City.

${ }^{6}$ Chakraborty and Armstrong (1997) find consistent results for block groups buffered at different distances (for TRI emissions in Des Moines) as well as aggregated into exposure plumes, but noted that the magnitude of the results varied. Sheppard et al. (1999) demonstrate broadly consistent results for host block groups vs. block groups aggregated at 500-yard and 1,000-yard buffer radii around TRI facilities in Minneapolis. Cutter et al. (1996) address the MAUP and predict stronger correlations for larger scale units, though their results for multiple scales in South Carolina around hazard locations are not entirely consistent with their predictions. Dolinoy and Miranda (2004) find variation in the racial and class predictors of exposure to pollutants at the zip code, tract, block group, and block levels of analysis for Durham County, North Carolina. Sui (1999) discusses MAUP scale and zoning issues at length and examines model results at the zip code, tract, and block group scales as well as three other pre-defined scales and 50 randomly generated groupings of block groups. He concludes that coefficient magnitude is highly dependent on areal unit choice. Reported coefficients for this study are statistically significant in all cases, which is very uncommon in the literature. Taquino et al. (2002) find some difference in results between block groups, tracts, and zip codes in Mississippi, when analyzing exposure to industrial hog farms. They recommend using a constructed community measure as the optimal scale choice.

${ }^{7}$ Chi-square tests fail to reject independence of scale and EJ significance in Table 1A ( $\chi^{2}=16.03,4$ d.f.) and (marginally) for scope and EJ significance in Table 1B $\left(\chi^{2}=4.60,2\right.$ d.f)

${ }^{8}$ Of the $110 \mathrm{EJ}$ analyses reviewed, 35 provided at least one analysis at the national level.

${ }^{9}$ The basic logit model is useful for descriptive purposes, but it is difficult to see its derivation from even a simple structural model of the phenomena of interest. The equilibrium co-location of groups of residents and NPL siting and remediation involves several complex systems. In principle, a system of equations could be estimated to capture these simultaneous effects, given sufficient structure and data (recent examples using NPL sites include Cameron and McConnaha, 2006; Greenstone and Gallagher 2005; and Noonan et al., 2005). However, estimating a structural model describing both siting and locating is well beyond the efforts of most EJ studies (only 18 of the 110 studies reviewed for this paper had any dynamic analysis at all). Conventional EJ studies might be construed as reducedform models arising from such a system. Reduced-form models, such as the logits employed here, reveal little about 
the separate land-use allocation and residential location processes that yield the equilibrium observations. However, the reduced-form approach has advantages in simplicity and accessibility - as well as typically valid estimates of conditional means. Conditional on other factors, the logit enables researchers to identify whether environmental hazards are distributed evenly with respect to race, income, and other variables. Why this is the case may well be beyond the reach of the reduced-form models. But the estimated distributional equity is what it is: evidence of unequal environmental quality in the observed equilibrium.

${ }^{10}$ When estimating the models in Tables 4 and 5 with an otherwise identical linear probability model, Moran's I statistic suggests positive spatial autocorrelation in the error for only the zip code, tract, and block group scales at the California scope. Controlling for spatial autocorrelation minimally affects these estimates. Although less precision in the estimates is expected for positively correlated errors relative to spherical errors (see, e.g., Jerrett et al. 2001), this evidence does not suggest that controlling for spatial autocorrelation would change the results in Tables 4 or 5 substantially. 